У, $\triangle \mathrm{K} 342.2$

ББК 67.400 .5

DOI 10.22394/1682-2358-2019-1-88-92

Yu.A. Evtyukbin, Candidate of Sciences (Law), Docent of the Theory and History of State and Law Department, Kemerovo Institute (Branch) of Plekbanov Russian University of Economics

\section{SEPARATISTIC \\ ELEMENTS \\ IN THE DECLARATION \\ OF STATE \\ SOVEREIGNTY \\ OF THE RSFSR}

The contents of the Declaration of State Sovereignty of the Russian Soviet Federative Socialist Republic and the consequences of its enacting are considered. It is proved that some of the guidelines of this document challenged the entity of economical and legal framework of the USSR, and threatened the existence of the Russian statehood.

Key words and word-combinations: state sovereignty, separatism, entity of legal framework.
Ю.А. ЕВтюхин, кандидат юридических наук, доцент кафедри теории и истории государства и права Кемеровского института (филиала) Российского экономического университета имени Г.В. Плеханова (email: ewt-in@yandex.ru)

\section{СЕПАРАТИСТСКИЕ НАЧААА В АЕКААРАЦИИ О ГОСУ- ААРСТВЕННОМ СУВЕРЕНИ- TETE РСФСР}

\footnotetext{
Аннотация. Рассматривается содержание Декларации о государственном суверенитете РСФСР и последствия ее принятия. Доказывается, что некоторые нормы этого документа подрывали единство экономического и правового пространства СССР, ставили под угрозу существование российской государственности.

Ключевые слова и словосочетания: государственный суверенитет, се-паратизм, единство правового пространства.
}

момента принятия Аекларации о государственном суверенитете РСФСР прошио почти тридцать мет, но она продолжает привлекать внимание исследователей самых разных научных направлений - юриспруАенции, истории, политологии. Аокумент изучается студентами вузов и техникумов по программам нескольких учебных Аисциплин. Важно дать Аекларации о государственном суверенитете РСФСР объективную оџенку, так как в учебной митературе, как

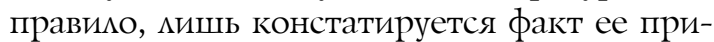
нятия и измагается краткое содержание без какой-либо оџенки $[1 ; 2]$. 
В научных публикациях, напротив, представлены мнения от положительных до резко негативных. Например, А.Ю. Винников пишет: «Аекларирование суверенитета РСФСР стало первым и наиболее важным шагом на пути становления Российского государства, поскольку неотъемлемым свойством мюбого государства явцяется суверенитет, без которого невозможно существование государства как самостоятельного субъекта права» [3, с. 99]. С иных позиций подходит к этому документу В.А. Овчинников. Он усматривает в нем одну из причин возникновения военного конфликта в Чеченской Республике: «ОАними из первых зерен, породивших эту трагедию и попавших на Чеченскую землю, были зерна Аекларации РСФСР “О государственном суверенитете РСФСР” $[4$, c. 40] . С.Г. Сергеев не находит юридического смысла в декларировании суверенитета РСФСР, так как он закреплялся в действовавших Конституциях СССР и РСФСР, и Ааже ставит под сомнение мегитимность Аекмарации [5, с. 35, 38] .

Гцавными цемями Аекларации о государственном суверенитете РСФСР, принятой народными депутатами РСФСР, явмялось следующее: сохранение российской государственности; преодоление сложной политической и соџиацьно-экономической ситуаџии, в которой тогда пребывацо государство; созАание условий Аля успешного Аемократического развития России. В этом убеждают не только их высказывания, отраженные в стенограмме Съезда народных депутатов РСФСР, но и мичные беседы с народными депутатами РСФСР от Кемеровской области В.Н. Цапаевым, В.И. Бочаровым, Г.А. Михайлецом, А.М. Тулеевым. Если судить по современной ситуации, названная цель была достигнута - Российское государство не прекратило существования и сохраницо свою целостность, хотя сепаратистские начала документа ставици под сомнение ее Аостижимость.

Некоторые народные депутаты РСФСР предполагали наличие центробежной силы, заложенной в Аекмарации. Так, У.Е. Темиров (Карачаево-Черкесская автономная обцасть), выступая в прениях по проекту Аекцарации, отмечал, что необоснованные претензии Съезда народных депутатов встать наА всесоюзным парламентом, союзным правительством далут Аругим союзным республикам аргументы последовать этому примеру, что поставит под угрозу существование СССР. Аепутат предостерег, что под угрозой может оказаться и российская государственность: «Если мы, народные депутаты России, позволим вести себя высокомерно по отношению к центральному правительству... то такой подхоА может возобладать и в автономных образованиях самой РСФСР по отношению как к нашему Российскому республиканскому правительству, так и Аруг к Аругу» [6, с. 486]. Слова У.Е. Темирова оказались пророческими.

В 1990-1991 гг. собственные Аекмараџии о государственном суверенитете были приняты практически во всех союзных республиках. В этих Аокументах не только закреплялись нормы, аналогичные нормам российской Аеклараџии, но и заявлялись права на долю в имуществе СССР. Хотя Советский Союз еще существовац, союзные республики, словно нетерпеливые наследники, декцарировали свое право на часть его золотого запаса, аммазного и валютного фондов. Республика Армения в своей Аекмарации о независимости Ааже закрепила право республики на свою долю вооружений СССР [7] .

Волна «суверенизации» прокатилась по автономиям и дошла до муници- 
пальных образований. Как вспоминает бывший председатель Верховного Совета Тувинской АССР Ч.-А. Ондар, в Туве Кара-Хаакский сельский Совет стремился объявить свой суверенитет [8, с. 11]. В различных источниках этот процесс получил название «парада суверенитетов».

Основную сепаратистскую угрозу таили в себе несколько статей Аекларации. Прежке всего это ст. 5, в которой закреплялось «исключительное право народа на владение, пользование и распоряжение наџиональным богатством России» [9]. Эта норма наносила удар по единству экономического пространства Советского Союза. Союзный центр мишался права регулировать экономические проџессы на территории РСФСР, и государственный суверенитет СССР остался без экономической основы.

Цитируемая статья Аекмарации наносила удар и по единству правового пространства Союза ССР, так как провозглашала верховенство Конституџии РСФСР и Законов РСФСР на всей территории России: «Аействие актов Союза ССР, вступающих в противоречие с суверенными правами РСФСР, приостанавливается Республикой на своей территории».

Важно, что Россия не первой подвергла сомнению суверенные прерогативы СССР. Ранее, 23 сентября 1989 г., это сделала Азербайджанская Респубцика. Прибалтийские республики оставим за рамками рассмотрения, так как юридически было признано, что в состав СССР они вошли недобровольно, а потому имели право восстановить свой государственный суверенитет.

В Конституционном законе Азербайджанской ССР от 23 сентября 1989 г. «О суверенитете Азербайджанской Советской Соџиалистической Республики» содержались положения, аналогичные по смыслу нормам ст. 5 Аекларации о государственном суверенитете РСФСР. Так, в ст. 10 закреплялось: «Земля, ее неАра, меса, воды и другие природные ресурсы Азербайджанской ССР явмяются наџиональным богатством, государственной собственностью республики и принадмежкат народу Азербайджана. Порядок пользования и эксплуатации природных ресурсов, находящихся на территории республики, устанавливается Верховным Советом АзербайАжанской ССР». В ст. 6 отмечалось: «Законы Азербайджанской ССР действуют на всей территории Азербайджанской ССР. На территории Азербайджанской ССР действуют Законы СССР, не нарушающие суверенные права Азербайджанской ССР». Таким образом, в сфере экономических отношений и правового регулирования Азербайджан закрепил свое верховенство [7, с. 158] .

Нельзя согласиться с широко распространенным в информационном пространстве Интернета утверждением, согласно которому распад Советского Союза начался с принятия Россией Аекларации о суверенитете. РСФСР не была первой в этом процессе. Она мишь поддержала его [8] .

Аругая норма, стимулировавшая внутренний сепаратизм в России, содержамась в ст. 9, в которой закреплялась необходимость существенного расширения прав автономных республик, автономных областей, автономных округов, а также краев и областей. В опредеменной мере это положение Аекларации носило вынужденный характер, потому что в законодательстве СССР статус автономных республик уже был поднят Ао уровня субъектов федерации Союза ССР [9] .

В автономных образованиях РСФСР Аостаточно скоро приступили к самостоятельному расширению своих прав, закрепляя их в декларациях о собс- 
твенном государственном суверенитете. За основу при этом был взят текст Аекларации о государственном суверенитете РСФСР. Некоторые субъекты Федерации предусмотрели право заключать договоры с иностранными государствами, а Чечено-Ингушская Республика «оставила за собой право на возмещение морального и материального ущерба, причиненного Республике и ее народу в 1944-1957 годах» [10].

Общеизвестна современная позиция Конституционного суда Российской Федерации, который считает невозможным «существование Авух уровней суверенных вмастей, находящихся в единой системе государственной власти» [11]. Но в тот период удержать автономии от объявления суверенитета не смогли бы никакие доводы. Российская государственность оказалась под реальной угрозой, единое экономическое и правовое пространство стремительно разрушалось. В Аальнейшем потребуются значительные усиция, в том числе и военные, чтобы его восстановить.

Можно предположить, что сепаратистские проџессы в России не были бы столь масштабны, если бы сначала Съезд народных депутатов РСФСР определим принципы национально-государственного и административно-территориального устройства Федерации, а ужк затем декларировал расширение прав

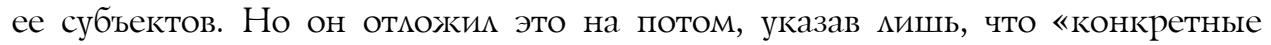
вопросы осушествления этих прав должны определяться законодательством РСФСР» (ст. 6 Аекларации).

Аекцараџия о государственном суверенитете РСФСР явилась катализатором сепаратистских настроений в автономиях Аругих союзных респубцик. 25 августа 1990 г. на X сессии Верховного Совета Абхазской АССР быма принята Аеклараџия о государственном суверенитете Абхазской Советской Соџиалистической Республики. Этому примеру последовац и Совет народных депутатов Юго-Осетинской автономной области, принявший 20 сентября 1990 г. Аеклараџию о государственном суверенитете Юго-Осетинской Советской Аемократической Республики. Государственности Грузии, в состав которой входили эти автономии, был нанесен существенный удар. Так, в абхазской Аекларации говорилось: «Аействия актов Союза ССР и Грузинской ССР, нарушающих суверенитет Абхазской ССР и вступающих в противоречие с ее правами, приостанавциваются высшими органами законодательной и исполнительной власти Абхазской ССР» [12]. В Аеклараџии Юго-Осетинской автономной области Грузия вообще не упоминалась.

Содержкание ряда статей этих документов дословно совпадает с текстом Аекларации о государственном суверенитете РСФСР, что позволяет утвержАать ее значение в качестве образца при их написании.

Более самостоятельным явцяется содержкание Аекларации о государственном суверенитете Крыма, принятой Верховным Советом Крымской АССР 4 сентября 1991 г. Хотя в ней признавался государственный суверенитет Украины, в состав которой входияа автономия, верховенство в сфере экономических отношений переходило к властям Крыма. В ст. 4 Аекларации отмечалось: «Народ Крыма имеет искцючительное право собственности на землю, ее недра, воздушное пространство, водные и другие природные ресурсы, находящиеся в пределах территории и континентального шельфа Крыма. Экономический и научно- 
технический потенџиал, созданный на территории республики, явмяется ее собственностью, материальной основой суверенитета и используется в интересах ее граждан» [13]. 5 мая 1992 г. на основе провозглашенной Аеклараџии и результатах референдума, проведенного в Крыму, Республика Крым объявика себя независимым государством, оформив это решение в Акте о провозглашении государственной самостоятельности Республики Крым. Украинская ССР прияожила немало усилий, чтобы сохранить Крым в своем составе.

Таким образом, Аеклараџия о государственном суверенитете РСФСР явимась детонатором сепаратизма не только в СССР и в России, но и в ряде союзных респубцик. Произошло это во многом потому, что парламент РСФСР при ее принятии не спрогнозировал возможные последствия. Поспешность и политизированность решения важнейшего вопроса о суверенитете привела к нежекательным негативным результатам.

\section{Библиографический список}

1. Юсубов Э.С., Макариев А.А. Конституционное право России: учебное пособие. Т. 1: Общая часть. Томск, 2015.

2. Конституционное право Российской Федерации: учебник для ФНО (средних учебных заведений) / под ред. И.А.Умновой, И.А.Алешковой. М., 2014.

3. Винников А.Ю. К вопросу о месте и роли Декларации о государственном суверенитете РСФСР в становлении Российского государства // Вестник Челябинского государственного университета. Право. 2011. № 29 (244). С. 99-103.

4. Овчинников В.А. Декларация о государственном суверенитете РСФСР и ее правовая оценка // Управленческое консультирование. 2013. № 5. С. 37-41.

5. Сергеев С.Г. Декларация о государственном суверенитете России // Гражданин и право. 2011. № 12. С. 33-45.

6. І Съезд народных депутатов РСФСР, 16 мая - 22 июня 1990 г.: стеногр. отчет: в 6 т. М., 1992. Т. 3.

7. К Союзу суверенных народов: сборник документов КПСС, законодательных актов, деклараций, обращений и президентских указов, посвященных проблеме национально-государственного суверенитета / сост. А.И. Доронченков. М., 1991. С. 155-229.

8. Ондар Ч.-Д.Б. Принятие Декларации о государственном суверенитете Советской Республики Тува // Новые исследования Тувы: электронный информационный журнал. 2012. № 2. C. 10-28. URL: https://elibrary.ru/item.asp?id=18216534 .

9. Декларация о государственном суверенитете РСФСР. Принята I Съездом народных депутатов РСФСР 12 июня 1990 г. // Ведомости Съезда народных депутатов и Верховного Совета РСФСР. 1990. № 2. Ст. 33.

10. Декларация о государственном суверенитете Чечено-Ингушской Республики от 27 нояб. 1990 г.: принята на внеочередной IV сессии Верховного Совета ЧИР. URL: https:// chechenlaw.ru/?p=55

11. По делу о проверке конституционности отдельных положений Конституции Республик Алтай и Федерального закона «Об общих принципах организации законодательных (представительных) и исполнительных органов государственной власти субъектов Российской Федерации: постановление Конституционного суда РФ от 7 июня 2000 г. № 10-П. URL: http://www. consultant.ru/document/cons_doc_LAW_27571/

12. Декларация о государственном суверенитете Абхазской Советской Социалистической Республики: принята Х сессией Верховного Совета Абхазской АССР ХІ созыва 25 авг. 1990 г. URL: http://www.apsuara.ru/portal/book/export/html/1013

13. Декларация о государственном суверенитете Крыма: принята Верховным Советом Крымской ACCP 4 сент. 1991 г. URL: https://news2.ru/story/501920/ 